Vol 1. No 3. Juli 2021 P-ISSN : 2774-8022, e-ISSN : 2774-5791

\title{
HUBUNGAN GAYA BELAJAR DENGAN HASIL BELAJAR SISWA MATA PELAJARAN PENDIDIKAN ISLAM DI KELAS VII SMPN 1 PELEPAT MUARA BUNGO TAHUN PELAJARAN 2017/2018
}

\author{
MISLIAWATI \\ SMP Negeri 1 Pelepat, Muara Bungo, Provinsi Jambi \\ Email : wmislia7@gmail.com
}

\begin{abstract}
ABSTRAK
Penelitian ini bertujuan untuk mengetahui: 1) hubungan gaya belajar visual siswa kelas VII dengan hasil belajar mata pelajaran Pendidikan Agama Islam di SMPN 1 Pelepat Muara Bungo. 2) hubungan gaya belajar auditorial siswa kelas VII dengan hasil belajar mata pelajaran Pendidikan Agama Islam di SMPN 1 Pelepat Muara Bungo. 3) hubungan gaya belajar kinestetik siswa kelas VII dengan hasil belajar mata pelajaran Pendidikan Agama Islam di SMPN 1 Pelepat Muara Bungo. 4) hubungan gaya belajar siswa kelas VII dengan hasil belajar mata pelajaran Pendidikan Agama Islam di SMPN 1 Pelepat Muara Bungo. Pendekatan penelitian yaitu kuantitatif, jenis yaitu penelitian asosiatif. Sampel dalam penelitian ini adalah siswa kelas VII-A dan VII-C yang berjumlah 70 siswa. Metode pengambilan data; 1) kuesioner model skala likert untuk variabel bebas yaitu gaya belajar visual, auditorial dan kinestetik, 2) dokumentasi untuk variabel terikat yaitu hasil belajar Pendidikan Agama Islam. Teknik analisis data: untuk menguji hipotesis adalah dengan teknik analisis regresi. Hasil penelitian: 1). Ada hubungan positif signifikan gaya belajar visual siswa kelas VII dengan hasil belajar mata pelajaran Pendidikan Agama Islam di SMPN 1 Pelepat Muara Bungo. 2). Ada hubungan positif yang signifikan gaya belajar auditorial siswa kelas VII dengan hasil belajar mata pelajaran Pendidikan Agama Islam di SMPN 1 Pelepat Muara Bungo. 3). Ada hubungan positif yang signifikan gaya belajar kinestetik siswa kelas VII dengan hasil belajar mata pelajaran Pendidikan Agama Islam di SMPN 1 Pelepat Muara Bungo. 4). Ada hubunganpositif yang signifikan gaya belajar siswa kelas VII dengan hasil belajar mata pelajaran Pendidikan Agama Islam di SMPN 1 Pelepat Muara Bungo.
\end{abstract}

Kata Kunci:Inkuiri, minat baca, pengetahuan

\section{PENDAHULUAN}

Pendidikan adalah usaha yang dijalankan oleh seseorang atau kelompok orang lain agar menjadi dewasa atau mencapai tingkat hidup atau penghidupan yang lebih tinggi dalam arti mental. Sehingga dari sini dapat dipahami bahwasanya pendidikan itu merupakan suatu proses untuk mengembangkan diri dalam berbagai bidang kehidupan yang dilakukan secara utuh dan menyeluruh sepanjang hayat kehidupan manusia. Tujuan pendidikan ialah perubahanperubahan yang diharapkan terjadi pada subyek diri setelah mengalami proses pendidikan. Perubahan-perubahan itu antara lain perubahan pada tingkah laku individu, kehidupan pribadi individu. Tujuan pendidikan tidak akan tercapai tanpa adanya proses pembelajaran yang baik dan tepat.

Proses pembelajaran merupakan suatu proses interaksi antara siswa dengan pengajar dan sumber belajar dalam suatu lingkungan, sehingga proses pembelajaran menjadi sebuah rangkaian kegiatan interaksi antara guru dan siswa atas dasar ikatan timbal balik yang terjadi demi suatu tujuan tertentu.

Keberhasilan suatu proses pembelajaran dapat diamati dari dua sisi, yaitu tingkat pemahaman dan penguasaan materi yang diberikan oleh guru. Pemahaman seorang siswa berhubungan dengan daya serap seorang siswa dalam pembelajaran. Daya serap siswa adalah kemampuan atau kekuatan untuk melakukan sesuatu, untuk bertindak dalam menyerap pelajaran oleh setiap siswa. Salah satu kendala dalam proses pembelajaran di sekolah adalah adanya perbedaan daya serap individual di antara anak yang satu dengan anak yang lainnya, walaupun dalam lingkungan dengan umur yang sama dan kelas yang sama, yang pada akhirnya 
mengakibatkan hasil belajar kurang maksimal. Kecenderungan seseorang untuk belajar sangat beragam dan dipengaruhi oleh beberapa hal. Cara seseorang menyerap informasi, mengolahnya, dan memanifestasikan dalam wujud nyata perilaku hidupnya disebut dengan gaya/tipe belajar. Setiap orang memiliki gaya dan tipologi belajar yang berbeda-beda, tetapi juga ada yang memiliki gaya/tipologi belajar sejenis. Pada kenyataannya, gaya dan tipologi belajar berpengaruh terhadap hasil yang diperolehnya. Dalam realitas kehidupan sehari-hari, ada sebagian yang mudah menerima informasi baru dengan mendengarkan langsung dari sumbernya, ada yang cukup dengan tulisan atau memo, dan ada yang harus didemonstrasikan aktivitasnya. Hal tersebut menunjukkan adanya gaya/tipe belajar pada manusia. Gaya/tipologi belajar dapat dibagi menjadi tiga. Hal ini didasarkan pada cara seseorang menyerap informasi, mengolah, dan menyampaikannya, serta secara universal atau bagaimana seseorang tersebut belajar (Ula, 2013: 31).

Berdasarkan fenomena yang ada khususnya pada pelajaran pendidikan agama Islam, siswa lebih suka guru mereka mengajar dengan cara menuliskan segalanya di papan tulis. Dengan begitu mereka bisa membaca untuk kemudian mencoba memahaminya. Akan tetapi, sebagian siswa lain lebih suka guru mengajar dengan cara menyampaikannya secara lisan dan mereka mendengarkan untuk bisa memahaminya. Cara lain yang juga kerap disukai banyak siswa adalah model belajar yang menempatkan guru tak ubahnya seorang penceramah. Guru diharapkan bercerita panjang lebar tentang beragam teori dengan segudang ilustrasinya, sementara para siswa mendengarkan sambil menggambarkan isi ceramah itu dalam bentuk yang hanya mereka pahami sendiri.

Kemampuan seseorang untuk memahami dan menyerap pelajaran sudah pasti berbeda tingkatnya. Ada yang cepat, sedang dan ada pula yang sangat lambat. Karenanya, mereka seringkali harus menempuh cara berbeda untuk bisa memahami sebuah informasi atau pelajaran yang sama. Cara belajar yang dimiliki oleh siswa sering disebut dengan gaya belajar. "Gaya belajar "learning style" siswa, yaitu cara ia bereaksi dan menggunakan perangsang-perangsang yang diterimanya dalam proses belajar. Nasution, 2011: 93). Lebih lanjut definisi gaya belajar adalah "cara dimana anak-anak menerima informasi baru dan proses yang akan mereka gunakan untuk belajar. Sebagian anak menerima informasi lebih baik dengan cara visual, sebagian lagi dengan cara auditori, sementara yang lain memiliki kemungkinan lebih efektif menerima informasi dari taktil'. (Priyatna, 2013: 3). Apa pun cara yang dipilih, perbedaan gaya belajar itu menunjukkan cara tercepat dan terbaik bagi setiap individu untuk bisa menyerap sebuah informasi dari luar dirinya. (Uno, 2008: 67).

Penunjang penting dalam pencapaian hasil belajar siswa adalah gaya belajar yang terbagi tiga yaitu visual, auditory dan kinestetik. Gaya belajar seseorang merupakan kombinasi dari menyerap informasi dengan mudah dan kemudian mengatur serta mengolah informasi tersebut (DePorter dkk, 2018: 97). Setiap siswa menggunakan ketiga gaya ini pada tahapan tertentu, akan tetapi salah satu dari ketiganya cenderung lebih menonjol. Adanya perbedaan tersebut, guru harus mampu mengakomodasi kebutuhan siswa dalam kegiatan proses pembelajaran. Sehingga tujuan pembelajaran yang diharapkan dapat terpenuhi secara maksimal (Rijal \& Bachtiar, 2015: 15-20).

Gaya belajar merupakan cara termudah yang dimiliki oleh individu dalam menyerap, mengatur, dan mengolah informasi yang diterima. Gaya belajar yang sesuai adalah kunci keberhasilan siswa dalam belajar. Dengan menyadari hal ini, siswa mampu menyerap dan mengolah informasi dan menjadikanbelajar lebih mudah dengan gaya belajar siswa sendiri. Dalam Papilaya (2016: 56-63) dijelaskan bahwa gaya belajar peserta didik bisa diamati berdasarkan kecerdasan majemuk yang dimiliki dan tiap peserta didik memiliki kecerdasan dominan masing-masing. Penggunaan gaya belajar yang dibatasi hanya dalam satu bentuk, terutama yang bersifat verbal atau dengan jalur auditorial, tentunya dapat menyebabkan adanya ketimpangan dalam menyerap informasi. Oleh karena itu, dalam kegiatan belajar, siswa perlu dibantu dan diarahkan untuk mengenali gaya belajar yang sesuai dengan dirinya sehingga tujuan pembelajaran dapat dicapai secara efektif. (Bire, 2014: 44). 
Pendidikan Agama Islam (PAI) merupakan salah satu pelajaran yang materinya untuk peningkatan potensi spiritual dan membetuk peserta didik agar menajdi manusia yang beriman dan bertakwa kepada Tuhan Yang Maha Esa dan berakhlak mulia. Akhlak mulia mencakup etika, budi pekerti, dan moral sebagai perwujudan dari pendidikan agama. Peningkatan potensi spiritual mencakup pengamalan, pemahaman, dan penanaman nilai-nilai keagamaan, serta pengamalan nilai-nilai tersebut dalam kehidupan individual ataupun kolektif kemasyarakatan. Peningkatan potensi spiritual tersebut pada akhirnya bertujuan pada optimalisasi berbagai potensi yang dimiliki manusia yang aktualisasinya mencerminkan harkat dan martabatnya sebagai makhluk Tuhan, yang diberikan sejak dari tingkat Sekolah Dasar (SD) sampai perguruan tinggi. Pada umumnya materi Pendidikan Agama Islam dirasakan oleh siswa sulit untuk dipahami. Faktor penyebabnya antara lain, yaitu karena pelajaran Pendidikan Agama Islam (PAI) salah satu materinya berisikan peristiwa sejarah masa lalu dan tidak dialami oleh siswa dan apalagi cara belajar siswa dalam menyerap informasi berbeda-beda, sehingga di sekolah guru sering mengalami kesulitan dalam menjelaskan, banyak mengarah pada metode ceramah. Padahal apabila guru memberikan materi hanya dengan menggunakan metode tersebut maka tidak dapat menyesuaikan dengan kondisi atau keadaan siswa, selain itu metode tersebut membuat siswa kurang kreatif menggunakan semua aspek kecerdasannya. Oleh karena itu apabila seorang guru tidak mengenali gaya belajar siswa maka akan berdampak pada hasil belajar siswa. Banyak guru maupun peneliti yang mencoba memadukan model pembelajaran dalam pelajaran PAI untuk mencapai hasil belajar yang maksimal. Seperti Fitria (2019) yang dalam penelitiannya menggunakan model scramble berbasis powerpoint, ternyata mampu menaikkan rata-rata capaian hasil pembelajaran siswa pada mata pelajaran PAI. Begitu juga Nisa (2020) secara signifikan berhasil meningkatkan hasil pembelajaran PAI dengan melalui metode SAVI.

Salah satu cara untuk mengatasi kesulitan-kesulitan guru dalam memahamkan konsep pembelajaran PAI dan keberhasilan siswa pada pembelajaran PAI adalah dengan penggunaan model pembelajaran yang tepat, karena guru yang profesional sudah seharusnya mampu memilih dan menggunakan model pembelajaran sesuai dengan tujuan pembelajaran. (Zarkasi, 2020: 7)

Dengan demikian perlu dipilih model pembelajaran sesuai dengan kondisi materi, kondisi dan siswa, sehingga dapat meningkatkan hasil belajar siswa. Penguasaan konsep belajar dapat membantu siswa untuk mengaitkan antara materi yang diajarkan dengan situasi dunia nyata dan mendorong siswa membuat hubungan antara materi sejarah yang diterima dengan keterkaitannya dalam kehidupan sehari-hari.

\section{METODE PENELITIAN}

Penelitian ini menggunakan pendekatan kuantitatif atau analisis data statistik. Jenis pola penelitian yang digunakan adalah pola penelitian asosiatif yang digunakan untuk mengetahui hubungan antara dua variabel atau lebih. Data-data yang diperoleh diolah, dianalisis dan diproses dengan teori yang telah dipelajari sehingga dapat memperjelas gambaran mengenai objek yang diteliti. Adapun populasi dalam penelitian ini adalah seluruh siswa kelas VII SMPN 1 Pelepat Muara Bungo tahun pelajaran 2017/2018 dengan total 172 siswa. Penentuan sampel menggunakan Purposive sampling. Yang dijadikan sebagai sampel adalah seluruh siswa kelas VII-A dan VII-C yang berjumlah 70 orang dengan pertimbangan siswa dalam 2 kelas tersebut memiliki kemampuan yang homogen dan nilai rata-rata rapor yang berbeda-beda sehingga data yang diperoleh akan mewakili populasi. Adapun data yang dihasilkan dalam penelitian ini adalah: data primer meliputi hasil angket, nilai rapor, observasi dan wawancara. adapun data sekunder meliputi struktur organisasi SMPN 1 Pelepat Muara Bungo, denah lokasi, dan data lain yang relevan.

Adapun análisis regresi ganda pada penelitian ini digunakan untuk menguji hipótesis gaya belajar visual, auditorial, dan kinestetik berhubungan positif dengan hasil belajar siswa mata pelajaran Pendidikan Agama Islam di SMPN 1 Pelepat Muara Bungo. Langkah-langkah 
dalam regresi ganda sebagai berikut: 1). Persamaan garis regresi tiga prediktor: $Y=a+b_{1}$ $\mathrm{X}_{1}+\mathrm{b}_{2} \mathrm{X}_{2}+\mathrm{b}_{3} \mathrm{X}_{3}$. 2). Mencari koefisien determinasi antara prediktor $X_{1}, \mathrm{X}_{2}, \mathrm{X}_{3}$ dengan kriteria Y sebagai berikut:

$$
R y(1,2,3)=\frac{\sqrt{b 1 \sum X 1 Y+b 2 \sum X 2 Y+b 3 \sum X 3 Y}}{\sum y 2}
$$

3). Menguji keberartian regresi ganda, digunakan uji $F$ dengan rumus: $F h=\frac{\mathrm{R} 2(\mathrm{~N}-\mathrm{m}-1)}{\mathrm{m}(1-\mathrm{R} 2)}$

\section{HASIL DAN PEMBAHASAN}

Data hasil penelitian terdiri dari tiga variabel bebas yaitu variabel gaya belajar visual $\left(\mathrm{X}_{1}\right)$, gaya belajar auditorial $\left(\mathrm{X}_{2}\right)$ dan gaya belajar kinestetik $\left(\mathrm{X}_{3}\right)$ serta variabel terikat hasil belajar (Y).

\section{Hubungan Gaya Belajar Visual Siswa Kelas VII dengan Hasil Belajar Siswa}

Hasil penelitian ini menunjukkan bahwa terdapat hubungan positif dan signifikan antara gaya belajar visual dengan hasil belajar mata pelajaran Pendidikan Agama Islam siswa SMP Negeri 1 Pelepat Muara Bungo. Dari hasil analisis regresi satu prediktor diperoleh persamaan garis regresi $\mathrm{Y}=66,786+0,396 \mathrm{X}_{1}$, harga $\mathrm{F} h>\mathrm{F} t(12,76>3,98)$, dan $r=0,397$. Hal ini berarti apabila gaya belajar visual dinaikkan sebesar 1 poin maka hasil belajar akan naik sebesar 0,397 poin. Kemudian dari hasil analisis hubungan Product Moment menunjukkan bahwa gaya belajar visual mempunyai hubungan yang positif dengan hasil belajar mata pelajaran Pendidikan Agama Islam. Harga $\mathrm{F} h>\mathrm{F} t$ menunjukkan bahwa gaya belajar visual mempunyai hubungan yang signifikan dengan hasil belajar pelajaran Pendidikan Agama Islam siswa SMP Negeri 1 Pelepat Muara Bungo.

Makna dari hasil analisis regresi dan hubungan tersebut yaitu menunjukkan semakin tinggi gaya belajar visual siswa, maka akan semakin baik pula hasil belajarnya. Berarti terdapat hubungan yang positif dan signifikan gaya belajar visual dengan hasil belajar. Oleh karena itu dapat dikatakan bahwa semakin tinggi gaya belajar visual yang dimiliki oleh siswa akan memberikan hubungan yang signifikan dengan peningkatan hasil belajarnya. Berdasarkan teori yang diungkapkan oleh DePorter dan Hernacki bahwa siswa yang bergaya belajar visual, yang memegang peranan penting adalah mata/penglihatan (visual), mereka cenderung belajar melalui apa yang mereka lihat. Mereka belajar lebih cepat dengan menggunakan tampilantampilan visual, seperti diagram, buku pelajaran bergambar, dan video.

Mata pelajaran Pendidikan Agama Islam (PAI) dalam pembelajaran, guru lebih dominan untuk melakukan aktivitas visual dengan mewajibkan siswa untuk membaca buku paket dan buku LKS yang ditentukan. Siswa disuruh membaca dahulu sebelum guru mulai menjelaskan materi secara lisan. Besarnya kontribusi gaya belajar visual dengan hasil belajar ditunjukkan dengan hasil perhitungan koefisien determinasi atau koefisien penentu (KP). Setelah dianalisis ternyata variabel gaya belajar visual memberikan konstribusi dengan kenaikan hasil belajar sebesar $15,80 \%$ dan sisanya sebesar $84,2 \%$ berkaitan dengan variabel lain yang tidak dibahas dalam penelitian ini.

\section{Hubungan Gaya Belajar auditorial Siswa Kelas VII dengan Hasil Belajar Siswa}

Hasil penelitian ini menunjukkan bahwa terdapat hubungan positif dan signifikan gaya belajar auditorial dengan hasil belajar mata pelajaran Pendidikan Agama Islam siswa SMP Negeri 1 Pelepat Muara Bungo. Dari hasil analisis regresi satu prediktor diperoleh persamaan garis regresi $Y=65,067+0,409 \mathrm{X}_{2}$, harga $\mathrm{F} h>\mathrm{F} t(9,19>3,98)$, dan $\mathrm{r}=0,345$. Hal ini berarti apabila gaya belajar auditorial dinaikkan sebesar 1 poin maka hasil belajar akan naik sebesar 0,345 poin. Kemudian dari hasil analisis hubungan Product Moment menunjukkan bahwa gaya belajar auditorial mempunyai hubungan yang positif dengan hasil belajar mata pelajaran Pendidikan Agama Islam. Harga Fh > Ft menunjukkan bahwa gaya belajar auditorial mempunyai hubungan yang signifikan dengan hasil belajar mata pelajaran Pendidikan Agama 
Islam siswa. Makna dari hasil analisis regresidan hubungan tersebut yaitu menunjukkan semakin tinggi gaya belajar auditorial siswa, maka akan semakin baik pula hasil belajarnya.

Berarti terdapat hubungan yang positif dan signifikan gaya belajar auditorial dengan hasil belajar. Oleh karena itu dapat dikatakan bahwa semakin tinggi gaya belajar auditorial yang dimiliki oleh siswa akan memberikan hubungan yang signifikan dengan peningkatan hasil belajarnya. Dalam pembelajaran penugasan, siswa auditorial kesulitan untuk mengolah informasi dalam bentuk tulisan, sementara guru selalu menganjurkan untuk biasa menggunakan buku. Besarnya kontribusi gaya belajar auditorial dengan hasil belajar ditunjukkan dengan hasilperhitungan koefisien determinasi atau koefisien penentu (KP). Setelah dianalisis ternyata variabel gaya belajar auditorial memberikan konstribusi hubungan kenaikan hasil belajar sebesar $11,91 \%$ dan sisanya sebesar $88,09 \%$ berkaitan dengan variabel lain yangtidak dibahas dalam penelitian ini. Dari hasil penelitian ini kontribusiyang diberikan gaya belajar auditorial dengan hasil belajar mata pelajaran Pendidikan Agama Islam cukup berarti, hal ini disebabkan cara yang diterapkan guru dalam pembelajaran PAI telah menyesuaikangaya belajar siswanya yaitu menggunakan metode ceramah.

\section{Hubungan Gaya Belajar auditorial Siswa Kelas VII dengan Hasil Belajar Siswa}

Hasil penelitian ini menunjukkan bahwa terdapat hubungan positif dan signifikan gaya belajar kinestetik denganhasil belajar mata pelajaran Pendidikan Agama Islam siswa SMP Negeri 1 Pelepat Muara Bungo. Dari hasil analisis regresi satu prediktor diperoleh persamaan garis regresi $Y=70,153+0,281 \mathrm{X}_{3}$, harga $\mathrm{F} h>\mathrm{F} t(4,09>3,98)$, dan $\mathrm{r}=0,281$. Hal ini berarti apabila gaya belajar kinestetik dinaikkan sebesar 1 poin maka hasil belajar akan naik sebesar 0,281 poin. Kemudian dari hasil analisis hubungan Product Moment menunjukkan bahwa gaya belajar kinestetik mempunyai hubungan yang positif dengan hasil belajar mata pelajaran Pendidikan Agama Islam. Harga $\mathrm{F} h>\mathrm{F} t$ menunjukkan bahwa gaya belajar kinestetik mempunyai hubungan yang signifikan dengan hasil belajar mata pelajaran Pendidikan Agama Islamsiswa. Makna dari hasil analisis regresi dan hubungan tersebut yaitu menunjukkan semakin tinggi gaya belajar kinestetik siswa, maka akan semakin baik pula hasil belajarnya.

Berarti terdapat hubungan yang positif dan signifikan gaya belajar kinestetik dengan hasil belajar. Oleh karena itu dapat dikatakan bahwa semakin tinggi gaya belajar kinestetik yang dimiliki oleh siswa akan memberikan hubungan yang signifikan dengan peningkatan hasil belajarnya. Dalam pembelajaran mata pelajaran Pendidikan Agama Islam (PAI) itu sendiri biasanya guru memberikan sebuah game, dan sebelumnya guru memberikan contoh dan siswanya memperhatikan. Besarnya kontribusi gaya belajar kinesteti dengan hasil belajar ditunjukkan dengan hasil perhitungan koefisien determinasi atau koefisien penentu (KP). Setelah dianalisis ternyata variabel gaya belajar kinestetik memberikan konstribusi dengan kenaikan hasil belajar sebesar $05,68 \%$ dan sisanya sebesar $94,32 \%$ berkaitan dengan variabel lain yang tidak dibahas dalam penelitian ini.

\section{Hubungan Gaya Belajar Siswa Kelas VII dengan Hasi Belajar Mata Pelajaran Pendidikan Agama Islam}

Hasil dari analisis regresi ganda tiga prediktor diperoleh persamaan garis regresi $Y=$ $50,528+0,314 X_{1}+0,323 X_{2}+0,292 X_{3}$. Hal ini berarti apabila gaya belajar visual dinaikkan sebesar 1 poin maka hasil belajarnya naik sebesar 0,314 poin. Apabila gaya belajar auditorial dinaikkan sebesar 1 poin maka hasil belajar akan naik sebesar 0,323 poin. Sedangkan apabila gaya belajar kinestetik dinaikkan sebesar 1 poin maka hasil belajar akan naik sebesar 0,292 poin. Dari hasil analisis hubunganganda menunjukkan bahwa gaya belajar visual, auditorial, dan kinestetik mempunyai hubungan yang positif dengan hasil belajar mata pelajaran Pendidikan Agama Islam siswa SMP Negeri 1 Pelepat Muara Bungo. Hal ini dibuktikan dengan hasil analisis hubungan ganda yang diperoleh harga $\mathrm{R}_{\text {hitung }}=0,388$. Harga $\mathrm{F} h>\mathrm{F} t(3,89$ $>2,75)$ menunjukkan bahwa arah regresi signifikan atau berarti. Dengan demikian dapat dikatakan bahwa semakin tinggi gaya belajar maka hasil belajar akan semakin meningkat. Dari 
hasil penelitian ini besarnya kontribusi gaya belajar visual, auditorial, dan kinestetik dengan hasil belajar ditunjukkan dengan hasil perhitungan koefisien determinasi atau koefisien penentu (KP). Setelah dianalisis ternyata variabel gaya belajar visual, auditorial, dan kinestetik memberikan konstribusi dengan kenaikan hasil belajar sebesar15,21\% dan sisanya sebesar $84,79 \%$ berkaitan dengan variabel lain yang tidak dibahas dalam penelitian ini.

Data analisis penelitian ini menunjukkan bahwa variabel gaya belajar visual, auditorial, dan kinestetik memberikan konstribusi dengan kenaikan hasil belajar yang cukup berarti. Ini menunjukkan bahwa sebenarnya siswa menyadari gaya belajarnya. Tetapi mePAIpun sadar mereka harus lebih mengoptimalkan lagi gaya belajar yang mereka miliki. Untuk mengoptimalkan gaya belajar siswa maka diperlukan peran guru untuk mengajak siswanya mengenali dan memahami gaya belajarnya serta dapat memberdayakan gaya belajar tersebut semaksimal mungkin.

\section{KESIMPULAN}

Berdasarkan hasil penelitian dan pembahasan maka dapat disimpulkan bahwa: 1) Ada hubungan yang positif lagi signifikan antara gaya belajar visual siswa kelas VII dengan hasil belajar mata pelajaran Pendidikan Agama Islam di SMP Negeri 1 Pelepat Muara Bungo. 2) Ada hubungan yang positif lagi signifikan antara gaya belajar auditorial siswa kelas VII dengan hasil belajar mata pelajaran Pendidikan Agama Islam di SMP Negeri 1 Pelepat Muara Bungo. 3) Ada hubungan yang positif lagi signifikan antara gaya belajar kinestetik siswa kelas VII dengan hasil belajar mata pelajaran Pendidikan Agama Islam di SMP Negeri 1 Pelepat Muara Bungo. 4) Ada hubungan yang positif lagi signifikan antara gaya belajar siswa kelas VII dengan hasil belajar mata pelajaran Pendidikan Agama Islam di SMP Negeri 1 Pelepat Muara Bungo.

\section{DAFTAR PUSTAKA}

B. Uno, Hamzah. (2008). Orientasi baru dalam psikologi pembelajaran. Jakarta: PT. Bumi Aksara.

Bire, A. L., Geradus, U., \& Bire, J. (2014). Pengaruh gaya belajar visual, auditorial, dan kinestetik terhadap prestasi belajar siswa. Jurnal Keguruan: Penelitian Inovasi Pembelajaran, 44(2).

Deporter, bobby dan Mike Hernacki. (2018). Quantum Learning. Membiasakan Belajar Nyaman dan Menyenangkan. Bandung: Kaifa.

Euis, Sofi. (2016). Pembelajaran Berbasis e-learning Pada Mata Pelajaran Pendidikan Agama Islam Kelas VIII Madrasah Tsanawiyah Negeri. Jurnal Penelitian Manajemen Pendidikan, 1(1), 49-64.

Fitria, D., \&Andriesgo, J. (2019). Penerapan model pembelajaran scramble berbasis powerpoint untuk meningkatkan hasil belajar siswa pada bidang studi Pendidikan Agama Islam. J-PAI: Jurnal Pendidikan Agama Islam, 5(2).

Nasution, S. (2011). Berbagai Pendekatan Dalam Proses Belajar \& Mengajar. Jakarta: PT. Bumi Aksara.

Nisa, D. N., \&Lisnawati, S. (2020). Pengaruh metode somatic auditory visual intellectual (Savi) terhadap hasil belajar PAI. Al-Tadzkiyyah : Jurnal Pendidikan Islam, 11(1), 7382.

Papilaya, J. O., \& Huliselan, N. (2016). Identifikasi gaya belajar mahasiswa. Jurnal Psikologi, 15(1), 56-63.

Priyatna, Andi. 2013. Pahami Gaya Belajar Anak!. Jakarta: PT. Elex Media Komputindo Kelompok Gramedia.

Rijal, S., \& Bachtiar, S. (2015). Hubungan antara sikap, kemandirian belajar, dan gaya belajar dengan hasil belajar kognitif siswa. Jurnal Bioedukatika, 3(2), 15-20.

Ula, S.S. (2013). Revolusi Belajar: Optimalisasi Kecerdasan Melalui Pembelajaran Berbasis Kecerdasan Majemuk. Yogya-karta: Ar Ruzz Media. 
Zakaria, A. (2017). Pengaruh budaya literasi terhadap prestasi belajar Pendidikan Agama Islam siswa di SMP Iskandar Said Surabaya (Doctoral dissertation, UIN Sunan Ampel Surabaya).

Zarkasi, A. (2020). Perbandingan Hasil Belajar Siswa Menggunakan Metode Story Telling Dengan Metode Role Playing Pada Mata Pelajaran Pai Kelas V Min 3 Kota Banjarmasin. Skripsi. 